\title{
The incidence of Drug- Resistant Mutants in Patients With Chronic HBV Infection After Lamivudine Treatment
}

\author{
Sepide Ezzatpanah Fard ${ }^{1,2}$, Zohreh Sharifi $^{1, *}$, Seyed Masoud Hosseini ${ }^{2}$, Mahmood Mahmoodian \\ Shooshtari ${ }^{1}$ \\ ${ }^{1}$ Blood Transfusion Research Center, High Institute for Research and Education in Transfusion Medicine, Tehran, IR Iran \\ ${ }^{2}$ Department of Microbiology, Shahid Beheshti University of Medical Sciences, Tehran, IR Iran \\ ${ }^{*}$ Corresponding author: Zohreh Sharifi, Blood Transfusion Research Center, High Institute for Research and Education in Transfusion Medicine, Tehran, IR Iran, E-mail: z.sharifi@ \\ ibto.ir.
}

Received: July 22, 2012; Revised: October 29, 2012; Accepted: December 8, 2012

\begin{abstract}
Background:Hepatitis B virus (HBV) is replicated through reverse transcription of polymerase gene. Lamivudine can postpone the clinical progression in Hepatitis B infected patients, but the long-term monotherapy causes the emerge of YMDD (tyrosine-methionine-aspartateaspartate), LLAQ (leucine-leucine-alanine-glutamine) motifs and increases the Alanine aminotransferase (ALT) and HBV DNA levels.

Objectives: The aim of this study was to investigate rtL180M and rtM204V mutations in polymerase gene of HBV in infected patients after Lamivudine therapy.

Patients and Methods: Fifty sera samples collected from patients who referred to Blood Transfusion Center in Tehran were studied. The samples were divided into two groups; treated and untreated based on antiviral treatment status. From 50 patients, $34 \%$ were males and $66 \%$ were females, aged between 18 and 80 years. All of samples were tested for anti hepatitis B e antibody (anti-HBe), hepatitis B e antigen (HBeAg), hepatitis B surface antigen (HBsAg) and hepatitis B core antibody (anti-HBc) by enzyme-linked immunosorbent assay (ELISA) method. The ALT levels were measured using a commercial kit. Then HBV-DNA was extracted from serum samples using a commercial kit and a fragment of the P gene was amplified by nested PCR. Also, HBV viral load was detected by Real-Time PCR. HBV genotypes and polymerase gene mutations were determined by direct sequencing of the polymerase gene of HBV. Phylogenetic tree was constructed using neighbor-joining(NJ)method.

Results: About 6\% (3 of 50) of samples were HBeAg positive and 94\% (47 of 50) of patients were HBeAg negative by ELISA method. The patients' ALT level was between 16 and $95 \mathrm{IU} / \mathrm{L}$ with the mean of $37.58 \mathrm{IU} / \mathrm{L}$. Also, 48\% (24 of 50) of samples had <104 IU/mL viral load, $52 \%$ (26 of 50) of them had $>104 \mathrm{IU} / \mathrm{mL}$ viral load. About 10\% (5 of 50) of samples was treated with Lamivudine with specific substitution of amino acid located at codons 80,180 and 204. In addition, phylogenetic tree showed that genotype D of HBV was dominant among Iranian HBV infected patients

Conclusions: This study showed that the presence of mutation at codons rtL80V, rtL180M and rtM204V in A, B and C domains is associated with higher viral load and resistance to Lamivudine (3TC) respectively.
\end{abstract}

Keywords: YMDD Mutant; Polymerase Gene; Hepatitis B Virus; Lamivudine

\section{Background}

Hepatitis B infection has three states, acute, chronic and asymptomatic carrier. Hepatitis $B$ virus (HBV) infection ranks as the tenth leading cause of death (1). HBV strains are divided into 8 genotypes $(\mathrm{A}-\mathrm{H})$, based upon an inter- group divergence of at least 8 percent in the complete nucleotide sequence (2), with almost similar clinical manifestations of all these genotypes (3). Also HBV is divided into 9 serologic groups based on HBV surface antigen (HBs Ag) $(4,5)$.

Chronic hepatitis B (CHB) infection causes developing cirrhosis, hepatic decompensation and hepatocellular carcinoma $(1,6)$. This disease is common in Asia and Africa whereas is not common in Western countries (1). HBV has high mutational rate due to the presence of active replication and high number of viral copy production as well as lack of proofreading activity in HBV polymerase (6).

HBV genotypes do not spread with the same incidence in the world $(7,8)$. Genotype D has the most prevalence in Mediterranean region, India, Southern Europe, North and South Africa (9). Previous investigations showed that predominance serotype D was found in Iran $(10,11)$. The length of HBV genome is 3200 base pairs (bp) encoding four known genes, called C, X, P and S (12). The P gene encodes a polypeptide (90 kD), with four different activities; the terminal protein (TP) acts as a primer for synthesis negative DNA strand, the RT enzyme uses RNA as a tem-

Implication for health policy/practice/research/medical education:

In order to reduce of liver damage in the group of chronic hepatitis B patients with Lamivudine therapy that causes the mutations in P gene of HBV and no response to treatment.

Copyright (C) 2013, Ahvaz JundishapurUniversity of Medical Sciences; Published by Kowsar Corp. This is an open-access article distributed under the terms of the Creative Commons Attribution License, which permits unrestricted use, distribution, and reproduction in any medium, provided the original work is properly cited. 
plate for negative DNA strand transcript, RNase-H decomposes RNA template, and DNA polymerase enzyme synthesizes positive DNA strand from negative DNA strand (13).

The purpose of HBV infected patient treatment is to suppress virus replication, long-lasting maintenance of undetectable levels of serum HBV DNA and prevention of liver damage (14). Nowadays Antiviral agents are oral nucleoside analogues such as Lamivudine (LAM), Etecavir (ETV), Telbivudine (TBV), Adefovir (ADV) and Tenofovir (TDF) that are used for chronic hepatitis B management. These antiviral agents inhibit HBV reverse transcriptase and also control HBV replication, enhancing hepatitis B e antigen $(\mathrm{HBeAg})$ serocon version and reducing liver damages $(15,16)$. The best antiviral agent is determined by its ability to act as a competitive inhibitor of the HBV polymerase relative to that of the natural substrate (15). Long term use of nucleotide/nucleoside analogues can lead to viral resistance.

Lamivudine (B-L, 2-3-dioxy-3-thiacytidine) has the highest rate of antiviral resistance and Entecavir has the least rate of mutation resistance (15). Mutations that cause resistance to nucleoside/nucleotide analogues mainly involve polymerase gene and this gene contains 7 functional domains (A-G) and these mutations are located essentially in domain A through E (14). Factors such as age, gender, and disease status had no effect on the incidence of Lamivudine-resistant mutations (17). Due to drug resistance mutations, recent studies suggest the need for a combinational antiviral therapy (18).

\section{Objectives}

In this study the presence of rtL180M and rtM204V mutations in the HBV polymerase gene was investigated using the sequencing method among hepatitis B infected patients after lamivudine treatment.

\section{Patients and Methods}

\subsection{Patients}

Fifty sera from patients, who referred to Blood Transfusion Center in Tehran, were collected in 2011. A total of 50 patients were included in this study, there were 17 (34\%) male and 33 (66\%) female aged between 18 and 80 years (mean 40.6). Based on the antiviral therapy procedure, patients divided into two groups;1) HBV infected Patients (27 cases that treated with lamivudine $(100 \mathrm{mg} / \mathrm{dL}$ ) with a mean treatment period of 18 months and 2) HBV infected patients (23 cases) not treated with lamivudine. Also, patients who were not treated with other antiviral drugs excluded from this study. All of sera samples were stored at $-70^{\circ} \mathrm{C}$ for further study. The questionnaires were completed by patients finally.

\subsection{ELISA Method}

All patients were tested for serologic factors including hepatitis B surface antigen (HBsAg), hepatitis B e antigen (HBeAg), hepatitis B e antibody (anti-HBe) and hepatitis B core antibody (anti-HBc) by enzyme-linked immunosorbent assay (ELISA) method using DIA.PRO kit All serological tests were performed as instructed by the manufacturers. Also the levels of ALT were measured using PARS AZMUN kit, Iran.

\subsection{Real Time PCR}

HBV DNA was extracted from serum samples using the QIAamp DNA mini kit (QIAGEN, Germany) according to manufacturer instructions. $200 \mu \mathrm{L}$ serum samples were used and eluted into $50 \mu \mathrm{L}$ of buffer. The HBV DNA levels were detected by Real Time PCR using Artus HBV LC PCR kit (Artus GmbH, Hamburg, Germany).

\subsection{Nested PCR}

The nested polymerase chain reaction assay (PCR) was carried out on extracted HBV DNA by specific primers (10). Briefly, The target polymerase gene was amplified in a 50 $\mu \mathrm{L}$ reaction consisting of $5 \mu \mathrm{L} 10 \times$ PCR buffer with $1.5 \mathrm{mM}$ $\mathrm{MgCl} 2,1 \mu \mathrm{L} 10 \mathrm{mM}$ dNTPs, $1 \mu \mathrm{L}$ of outer primer $10 \mathrm{pmol} / \mu \mathrm{L}$, $0.5 \mu \mathrm{L}$ AmpliTaq Gold DNA Polymerase $(5 \mathrm{U} / \mu \mathrm{L})$, and $36.5 \mu \mathrm{L}$ nuclease free water. The thermal profile used in Techneh thermocycler consisted of $94^{\circ} \mathrm{C}$ for 5 minutes, followed by 30 cycles at $94^{\circ} \mathrm{C}$ for 45 seconds, $63^{\circ} \mathrm{C}$ for 45 seconds, $72^{\circ} \mathrm{C}$ for 45 seconds, followed by a final extension at $72^{\circ} \mathrm{C}$ for 10 minutes and a final hold program at $4^{\circ} \mathrm{C}(10)$.

The outer primers were $\mathrm{F} 1$ (sense, nt 56-76, $5^{\prime}$-CCTGCTGGTGGCTCCAGTTC-3') and R1 (antisense, nt 1395-1416, 5'CGTCCCGCG (AC)AGGATCCAGTT -3') (10). In second round of Nested-PCR, $48 \mu \mathrm{L}$ master mix containing the primer F2 (sense, nt 298-320, 5' - CYTGGCCWAAATTCGCAGTCCC-3') and R2 (antisense, nt 997- 1019, 5'-GCAAANCCCAAAAGACCACAAT- $3^{\prime}$ ) and $2 \mu \mathrm{L}$ first round PCR products were used under the same conditions. The cycling profile for the second round PCR to produce amplicon, consisted of $94^{\circ} \mathrm{C}$ for 5 minutes, followed by 30 cycles at $94^{\circ} \mathrm{C}$ for 45 seconds, $56^{\circ} \mathrm{C}$ for 45 seconds, $72^{\circ} \mathrm{C}$ for 45 seconds, followed by a final extension at $72^{\circ} \mathrm{C}$ for 10 minutes and a final hold program at $4{ }^{\circ} \mathrm{C}$.

Then horizontal gel electrophoresis on $1 \%$ agarose gel in TAE $1 \mathrm{x}$ buffer at $85 \mathrm{~V} / \mathrm{1h}$ was carried out using ladder specific, a single 721 bp band was showed after the second round of Nested-PCR. The polymerase gene was amplified by PCR in a $100 \mu$ L volume and then was purified with high pure PCR product purification kit (Roche, Germany).

\subsection{HBV DNA Sequencing}

PCR product was sequenced with dideoxy method using PCR primer (Takapozist Co., Iran). The polymerase gene was analyzed using CEQ 8000 analysis software. Using the CLUSTAL W 1.8 software package, the nucleotide-sequences of HBV strains were aligned with a refer- 
ence panel of sequences representative of each subtype retrieved from the Gen Bank database. Phylogenetic tree was drawn using the neighbor joining method. The amino acid sequence encoded by the nucleotide sequence was also analyzed to assess possible drug mutations. Data were analyzed with SPSS, version $16(\mathrm{P}<0.05)$.

\section{Results}

A $6 \%$ (3 cases) of samples were HBeAg positive and 94\% (47 cases) of patients were HBeAg negative employed ELISA method. All patients were positive for HBV DNA by PCR assay that $48 \%$ (24 cases) of samples had a viral load of $<104 \mathrm{IU} / \mathrm{mL}$ and $52 \%$ (26 cases) of them had viral load $>$ $104 \mathrm{IU} / \mathrm{mL}$. The mean of HBV DNA level was $2 \times 10^{7} \mathrm{IU} / \mathrm{mL}$. About 54 \% (27 of 50 cases) of samples had treatment history with antiviral therapy using Lamivudine and 46\% (23 cases) of them had no treatment history. A 33.3\% (1 case) of HBeAg positive/HBeAb negative patients had the viral load less than $10^{4} \mathrm{IU} / \mathrm{mL}$ and $66.6 \%$ (2 cases) of them had the viral load more than $10{ }^{4} \mathrm{IU} / \mathrm{mL}$; none of them were treated. Also 49\% (23 from 47 cases) of HBeAg negative/ $\mathrm{HBeAb}$ positive patients had a viral load less than $10{ }^{4} \mathrm{IU} /$ $\mathrm{mL}$ and $51 \%$ (24 cases from 47 ) of them had a viral load more than $10{ }^{4} \mathrm{IU} / \mathrm{mL}$ that these patients had treatment history (Tables 1, 2).

The patients' ALT levels were between 16 and 95 IU/L with the mean of 37.58 IU/L. ALT levels in 18.5\% (5 of 27 cases) and $4 \%$ ( 1 of 23 cases) of treated and untreated patients were high, respectively. The PCR products were sequenced in the region of the HBV polymerase gene encoding the YMDD motif. Only 10\% (5 cases) of patients that were taken antiviral therapy had specific substitution of amino acid; L80V, L180M and M204V. These patients were HBeAg negative and had viral load of $>10^{4} \mathrm{IU} / \mathrm{mL}$.

\begin{tabular}{llll}
\hline \multicolumn{1}{l}{ Table 1. Frequency of HBeAg/HBeAb among Patients With Different Viral Load } & \\
\hline Viral Load & $<\mathbf{1 0}^{4} \mathbf{I U} / \mathbf{m L}$, No.(\%) & $>\mathbf{1 0}^{4} \mathbf{I U} / \mathbf{m L}$, No. (\%) & Total, No. (\%) \\
\hline HBeAg Positive/Anti-HBe Negative & $1(2)$ & $2(4)$ & $3(6)$ \\
HBeAg Negative/Anti-HBe Positive & $23(46)$ & $24(48)$ & $47(94)$ \\
Total & $24(48)$ & $26(52)$ & $50(100)$ \\
\hline
\end{tabular}

Table 2. Frequency of HBeAg/HBeAb in Treated and Untreated Patients With Different Viral Load

\begin{tabular}{llllll}
\hline Viral Load & \multicolumn{2}{c}{$<\mathbf{1 0}^{4} \mathbf{I U} / \mathbf{m L}$, No. $(\%)$} & \multicolumn{2}{c}{$>\mathbf{1 0}^{4} \mathbf{I U} / \mathbf{m L}$, No.(\%) } & \multirow{2}{*}{ Total, No. (\%) } \\
\cline { 2 - 5 } & Treated & Untreated & Treated & Untreated & $3(6)$ \\
\cline { 1 - 5 } HBeAg Positive/Anti-HBe Negative & - & $1(2)$ & - & $2(4)$ & $47(94)$ \\
HBeAg Negative/Anti-HBe Positive & $20(40)$ & $3(6)$ & $7(14)$ & $17(34)$ & $50(100)$ \\
\hline Total & $20(40)$ & $4(8)$ & $7(14)$ & $19(38)$ & 5 \\
\hline
\end{tabular}

Also, phylogenetic analysis results revealed that all HBVs infected the Iranian HBV patients were genotype D. The studied sequences from this study were compared with GenBank sequences in a BLAST search, the results of blast showed that $75 \%$ of isolates from this study were similar to Iranian isolates (accession No. JN040770). Also, 20\% and $5 \%$ of sequences were similar to isolates from other countries (Syria, accession No. JN257205 and Turkey, accession No. JF754628, respectively).

\section{Discussion}

Polymerase gene is responsible for reverse transcriptase in HBV but it does not have proof reading activity which causes these sort of mutations. By pressure created by the antiviral agents, the selected viruses had replicative advantage in presence of antiviral agents (15). Previous studies showed that using of Lamivudine may reduce serum HBV DNA levels and normal ALT levels in patients (19), however, long term use of Lamivudine cause emerging YMDD mutant and increasing in ALT and HBV DNA levels. Then, this is emphasis that all patients with high levels of viral load, after long term use of Lamivudine, should be examined for the presence of drug resistance in polymerase gene (20).

One of the factors that increase the risk of drug resistance is ALT, a high level of ALT and aspartate aminotransferase (AST) enzymes in the samples can be a sign of liver damage (12). The other factor is the incomplete suppression of viral replication (12). Detection of HBeAg is and indication of active replication in $\mathrm{HBV}(21)$. Also the anti-HBe antibody usually is a sign for inactivation of viral replication, or a response to treatment (21). Detection of HBV-DNA level is a criterion for determining the state of infection, the risk of progression toward cirrhosis and HCC, identification of patients who need antiviral therapy, and identifying emergence of drug resistance. In our study, despite the positivity of anti-HBe, $12.2 \%$ (6 cases) of patients had high ALT levels with the mean of $76 \mathrm{IU} / \mathrm{L}$ and the mean viral load was $5 \times 10^{6} \mathrm{IU} / \mathrm{mL}$.

The results of sequencing showed that $10 \%$ ( 5 cases) of treated patients had rtL180M / M204V mutations due to amino acid substitution from Leucine to methionine located in LLAQ motif (rtL180M) which were converted to LMAQ motif, also in YMDD motif (rtM204 V) due to the 
amino acid substitution from methionine to valine that were converted to YVDD motif and also, these patients had the amino acid substitution rtL80V in A domain. All these patients were received Lamivudine for a period of 18 months. The statistical results showed that there is a significant relationship between liver enzyme and viral load in patients with rtL180M / M204V mutations. These results were in agreement with a study on Japanese patients treated with Lamivudine that showing rtL80V (domain A) and rtL180M in conjunction with the M204V/I changes that conferred Lamivudine resistance. these doubles and triplicates changes are associated with higher viral loads (12).

Ghandehari et al. in 2011 showed that the rate of YMDD motif mutant in chronic hepatitis B virus infected patients who treated with lamivudine, was approximately $14 \%$ (22). another study in 2008 , reported a $31 \%$ rate YMDD mutation in 107 patients in North China (23). A study in 2005 showed that $41.3 \%$ of HBV infected patients had rtL180M / M204V mutation and also patients undergo the treatment with other medications than Lamivudine had shown no mutation, also this study indicated that rtM204V mutation is always combined with rtL180M and the occurrence rate of this kind of combinational mutation was $100 \%(23)$.

In our study mutation in polymerase gene was not observed in the all patients who have not received prior Lamivudine therapy. An investigation in Iranian population showed that patients without Lamivudine therapy had no rtL80M/M204V mutations (24). Also, another study on infected blood donors with HBV showed that Lamivudine resistance mutations (rtL180M / rtM204V) strains are not detected in Iranian blood donors (10). Sequence analysis of our study showed similar results with previous study, that genotype D of HBV was dominant among Iranian patients (10). Also, all HBV infected patients had the same amino acids including I92L, P110S, T119N, N122I, I123F, Y125H, D132N, K150Q, S224A, I225V, N249H, S257C,W258Y, T260S, E264D, V267I, L268Q,L270I, Q272E.

Also, sequence analysis showed that, $75 \%$ of the nucleotide sequence of $\mathrm{HBV}$ isolates had similarity with $\mathrm{HBV}$ isolates from Iranian patients and $25 \%$ had similarity with the nucleotide sequence of HBV isolates from other countries (Syria and Turkey), therefore the presence of these circulating isolates from Iranian patients may be the result of traveling to such countries.

In conclusion, $\mathrm{HBV}$ mutations which play an important role in Lamivudine resistance, usually located at polymerase gene, including rtM204V in C domain and rtL180M in B domain and L80V in A domain and triple mutations in this gene are associated with higher viral loads and level of ALT. Therefore evaluation of these sites of polymerase gene is necessary for detecting Lamivudine resistance in $\mathrm{HBV}$ patients treated with Lamivudine.

\section{Acknowledgements}

The authors would like to thank the Blood Transfusion Research Center, High Institute for Education and Research on Transfusion Medicine for supporting this study.

\section{Authors' Contribution}

None declared.

\section{Financial Disclosure}

The authors declare that they have no conflict of interest.

\section{Funding/Support}

None declared.

\section{References}

1. Chan K, Yam I, Yuen J, Yuen MF, Lai CL, Alexander GJ, et al. A comprehensive HBV array for the detection of HBV mutants and genotype. Clin Biochem. 2011;44(14-15):1253-60.

2. Ma Y, Ding Y, Juan F, Dou XG. Genotyping the hepatitis B virus with a fragment of the HBV DNA polymerase gene in Shenyang, China. Virol J. 2011;8:315.

3. Levinson Warren, Jawetz Ernest. Medical microbiology and immunology:: Appleton \& Lange; 2001

4. Blitz L, Pujol FH, Swenson PD, Porto L, Atencio R, Araujo M, et al. Antigenic diversity of hepatitis $\mathrm{B}$ virus strains of genotype $\mathrm{F}$ in Amerindians and other population groups from Venezuela.J Clin Microbiol.1998;36(3):648-51.

5. Orito E, Ichida T, Sakugawa H, Sata M, Horiike N, Hino K, et al Geographic distribution of hepatitis B virus (HBV) genotype in patients with chronic HBV infection in Japan. Hepatology. 2001;34(3):590-4.

6. Zhu R, Zhang HP, Yu H, Li H, Ling YQ, Hu XQ, et al. Hepatitis B virus mutations associated with in situ expression of hepatitis B core antigen, viral load and prognosis in chronic hepatitis B patients. Pathol Res Pract. 2008;204(10):731-42.

7. Furusyo N, Nakashima H, Kashiwagi K, Kubo N, Hayashida K, Usuda S, et al. Clinical outcomes of hepatitis B virus (HBV) genotypes $B$ and $C$ in Japanese patients with chronic HBV infection. Am JTrop Med Hyg. 2002;67(2):151-7.

8. Sallam TA, William Tong CY. African links and hepatitis B virus genotypes in the Republic of Yemen. J Med Virol. 2004;73(1):23-8.

9. Okamoto H, Tsuda F, Sakugawa H, Sastrosoewignjo RI, Imai M, Miyakawa Y, et al. Typing hepatitis B virus by homology in nucleotide sequence: comparison of surface antigen subtypes. J Gen Virol.1988;69 ( Pt 10):2575-83.

10. Sharifi Z, Yari F, Gharebaghiyan A. Sequence analysis of the polymerase gene in hepatitis B virus infected blood donors in Iran. Arch Iran Med. 2012;15(2):88-90.

11. Zali Mohammad Reza. Hepatitis B resistance in Iran. Gastroenterol Hepatol Bed Bench. 2010;3(2).

12. Locarnini S, Zoulim F. Molecular genetics of HBV infection. AntivirTher. 2010;15 Suppl 3:3-14.

13. Robinson SW. Hepatitis B Virus. 2 edNew York: Roven press LTd 1990.

14. Keeffe EB, Dieterich DT, Pawlotsky JM, Benhamou Y. Chronic hepatitis B: preventing, detecting, and managing viral resistance. Clin Gastroenterol Hepatol. 2008;6(3):268-74.

15. Chen $\mathrm{CH}$, Lee $\mathrm{CM}$, Tung WC, Wang JH, Hung $\mathrm{CH}$, Hu TH, et al Evolution of full-length HBV sequences in chronic hepatitis B patients with sequential lamivudine and adefovir dipivoxil resistance. J Hepatol. 2010;52(4):478-85. 


\section{Ezzatpanah Fard S et al.}

16. Vincenti D, Solmone M, Garbuglia AR, Iacomi F, Capobianchi MR A sensitive direct sequencing assay based on nested PCR for the detection of HBV polymerase and surface glycoprotein mutations. JVirol Methods. 2009;159(1):53-7.

17. Ghany MG, Doo EC. Antiviral resistance and hepatitis B therapy. Hepatology. 2009;49(5 Suppl):S174-84.

18. Liaw YF, Chien RN, Yeh CT, Tsai SL, Chu CM. Acute exacerbation and hepatitis B virus clearance after emergence of YMDD motif mutation during lamivudine therapy. Hepatology. 1999;30(2):567-72.

19. Tipples GA, Ma MM, Fischer KP, Bain VG, Kneteman NM, Tyrrell DL. Mutation in HBV RNA-dependent DNA polymerase confers resistance to lamivudine in vivo. Hepatology. 1996;24(3):714-7.

20. Leung NW, Lai CL, Chang TT, Guan R, Lee CM, Ng KY, et al. Extended lamivudine treatment in patients with chronic hepatitis B enhances hepatitis B e antigen seroconversion rates: results after 3 years of therapy. Hepatology. 2001;33(6):1527-32.

21. Liaw YF, Sung JJ, Chow WC, Farrell G, Lee CZ, Yuen H, et al. Lamivudine for patients with chronic hepatitis $\mathrm{B}$ and advanced liver disease. NEngl J Med. 2004;351(15):1521-31.

22. Ghandehari F, Pourazar A, Zadeh MS, Tajedin N. Probing rate of YMDD motif mutant in lamivudine treatment of Iranian patients with chronic hepatitis B virus infection. Asian J Transfus Sci. 2011;5(1):32-4.

23. Li D, Gu HX, Zhang SY, Zhong ZH, Zhuang M, Hattori T. YMDD mutations and genotypes of hepatitis B virus in northern China.Jpn JInfect Dis. 2006;59(1):42-5.

24. Ramezani A, Velayati AA, Roshan MR, Gachkar L, Banifazl M, Keyvani H, et al. Rate of YMDD motif mutants in lamivudine-untreated Iranian patients with chronic hepatitis B virus infection. Int J Infect Dis. 2008;12(3):252-5. 